\title{
Article \\ Composition and Functional Characteristics and Influencing Factors of Bacterioplankton Community in the Huangshui River, China
}

\author{
Qianqian Zhang ${ }^{1,+}$, Zhenbing Wu ${ }^{1,2,+} \mathbb{D}$, Juan Zhao ${ }^{3,4}$, Guojie Wang ${ }^{3,4}$, Jingwen Hao ${ }^{1,2}$, Shuyi Wang ${ }^{1,2}$, \\ Yaoyao Lin ${ }^{1,2}$, Hongtao Guan ${ }^{3,4}$, Jinyong Zhang ${ }^{5}$, Shenglong Jian ${ }^{3,4, *}$ and Aihua Li ${ }^{1, *}$
}

1 State Key Laboratory of Freshwater Ecology and Biotechnology, Institute of Hydrobiology, Chinese Academy of Sciences, Wuhan 430072, China; zqq@ihb.ac.cn (Q.Z.); wuzhenbing@ihb.ac.cn (Z.W.); haojingwen@ihb.ac.cn (J.H.); wangsy@ihb.ac.cn (S.W.); linyaoyao@ihb.ac.cn (Y.L.)

2 College of Life Sciences, University of Chinese Academy of Sciences, Beijing 100049, China

3 Qinghai Provincial Fishery Environmental Monitoring Center, Xining 810012, China; qhshnchx1@163.com (J.Z.); wangguojie178@163.com (G.W.); ght13139058581@163.com (H.G.)

4 Key Laboratory of Plateau Aquatic and Ecological Environmental in Qinghai Province, Xining 810012, China

5 The Laboratory of Aquatic Parasitology, School of Marine Science and Engineering, Qingdao Agricultural University, Qingdao 266237, China; zhangjy@ihb.ac.cn

* Correspondence: jianshenglong@163.com (S.J.); liaihua@ihb.ac.cn (A.L.); Tel.: +86-27-68780053 (A.L.)

+ These authors contributed equally to this work.

\section{check for} updates

Citation: Zhang, Q.; Wu, Z.; Zhao, J.; Wang, G.; Hao, J.; Wang, S.; Lin, Y.; Guan, H.; Zhang, J.; Jian, S.; et al. Composition and Functional Characteristics and Influencing Factors of Bacterioplankton Community in the Huangshui River, China. Microorganisms 2021, 9, 2260. https://doi.org/10.3390/ microorganisms 9112260

Academic Editor: Ulrich (Uli) Stingl

Received: 28 August 2021

Accepted: 26 October 2021

Published: 29 October 2021

Publisher's Note: MDPI stays neutral with regard to jurisdictional claims in published maps and institutional affiliations.

Copyright: (c) 2021 by the authors. Licensee MDPI, Basel, Switzerland. This article is an open access article distributed under the terms and conditions of the Creative Commons Attribution (CC BY) license (https:/ / creativecommons.org/licenses/by/ $4.0 /)$.
Abstract: Bacterial community plays a key role in environmental and ecological processes of river ecosystems. Given the special climatic and geographical conditions, studying the compositional characteristics of microorganisms in highland rivers and the relationship between such microorganisms and water physicochemical factors is important for an in-depth understanding of microbial ecological mechanisms. In the present study, high-throughput sequencing was used to investigate and study the bacterioplankton community of the Huangshui River in the ecotone zone of the Qinghai Plateau and Loess Plateau. The results showed that the Huangshui River had significantly lower alpha diversity than the plain rivers. Despite the similarity in their environmental conditions, the main taxonomic compositions of the bacterial communities were distinct between the Huangshui River and polar regions (the Arctic and Antarctica). Proteobacteria accounted for the largest proportion (30.79-99.98\%) of all the sequences, followed by Firmicutes (0-49.38\%). Acidiphilium was the most numerous genera, which accounted for $0.03-86.16 \%$ of the assigned $16 \mathrm{~S}$ reads, followed by Acidocella (0-95.9\%), both belonging to Alphaproteobacteria. The diverse taxa of potential pathogens, such as Acinetobacter, Pseudomonas, and Aeromonas, were also identified. A principal coordinates analysis, coupled with a canonical correspondence analysis, showed spatial variations in the bacterial community composition. The water physical properties (e.g., $\mathrm{Cr}^{6+}$, total phosphorus, and $\mathrm{COD}_{\mathrm{Mn}}$ ); altitude; and land use (e.g., urban land cover and aquaculture) determined the distribution of the bacterioplankton composition. PICRUSt2 revealed that the overall functional profiles of the bacterial communities in different samples were similar, and our results suggested the potential health risks of water sources in this area. This work provided valuable insight into the composition of the plankton bacterial community and its relationship with the environmental factors in the Huangshui River in the ecotone zone of the Qinghai Plateau and Loess Plateau and a theoretical foundation for ecological health management.

Keywords: Huangshui River; high-throughput sequencing; bacterioplankton community structure; environment factors; PICRUSt2 analysis

\section{Introduction}

Microorganisms are primary decomposers of organic compounds in natural ecosystems, which play a role in regional climate formation, the geochemical cycle, biological 
evolution, and natural ecosystems [1]. The distribution of microorganisms has attracted increasing interest in the last decade, and the diversity patterns of microbial communities have been widely observed [2]. Bacterioplanktons are essential for aquatic ecosystems [3], which are a fundamental and highly variable component of river ecosystems, exhibiting a comprehensive response to environmental pressure and disturbances [4-9]. Changes in the river water quality and ecological environment caused by human activities will lead to variations in the microbial community structure [10]. Several environmental factors have been considered as potential determinants of bacterial community compositions, including organic contaminants [11] and the concentration of nitrogen [12], phosphorous [13], and heavy metals [14]. By analyzing the changes in the microbial community structure, the state of a river ecosystem's health can be evaluated [15]. Therefore, investigating the diversity and structure of bacterial communities is important to understanding the response of bacteria to elevated environmental pressure in plateau rivers.

Qinghai Province, as the "Chinese water tower", is located in the west of China and in the northeastern part of the Qinghai Plateau. Its river ecosystem plays an important role in the ecological status of the whole province and even the whole of China. The Huangshui Basin is located in the transition zone between the Qinghai Plateau and the Loess Plateau, and it consists of the main stream area of the Huangshui River and the tributary Datong River. Given its particularity, the plateau has been considered as a sensitive area of the natural ecosystem, and its ecological environment is relatively fragile. Since the 20th century, the rapid development of human activities in industry, agriculture, mining, and overgrazing has caused outstanding problems in the aquatic environment, including the reduction of water resources, deterioration of water quality, and decline of aquatic biodiversity. Therefore, the ecological and environmental issues of plateau rivers need urgent attention.

Macrobenthic community compositions in the upper reaches of the Huangshui River have been reported. These works have only provided the community structure of macrobenthos, assessments of ecosystem health, and the quality of water in the Huangshui River $[16,17]$. However, bacteria play a critical role in environmental and ecological processes of river ecosystems. Exploring the composition of aquatic planktonic bacteria can provide a comprehensive understanding of accurate microbial distribution patterns and of the Huangshui River.

Here, as a complement to previous studies, $16 \mathrm{~S}$ rRNA gene high-throughput sequencing was conducted in the upper and middle reaches of the Huangshui River. The current study aimed to explore the composition and functional characteristics of the Huangshui River, identify key environmental driving factors, and understand the association of such driving factors with the bacterioplankton community. Based on previous reports, this study was the first to investigate the bacterioplankton community and its influencing factors in the Huangshui River.

\section{Materials and Methods}

\subsection{Study Sites and Sample Collection}

The Huangshui River, which is the largest tributary of the upper reaches of the Yellow River, is located in the intersecting zone of the Qinghai-Tibet Plateau and Loess Plateau $\left(36^{\circ} 02^{\prime}-38^{\circ} 20^{\prime} \mathrm{N}, 98^{\circ} 54^{\prime}-103^{\circ} 24^{\prime} \mathrm{E}\right)$, at an altitude of 1650 to $4400 \mathrm{~m}$, originating from the Baohutu Mountain in Haibei County, Qinghai Province and flowing into the Yellow River in Gansu Province [18]. The terrain in the basin is high in the northwest and low in the southeast, with high mountains and deep valleys. The climate belongs to the plateau arid and semi-arid continental climates, with vertical changes and large regional differences because of the diversity of the local topography. The temperature decreases as it goes upstream, whereas the precipitation increases, and the evaporation decreases. Moreover, humid marshes are found. The average annual temperature in the basin is $0.6-7.9{ }^{\circ} \mathrm{C}$, and the average annual precipitation is $360-540 \mathrm{~mm}$ [19]. 
The Baoku River is located in the northeast of Qinghai Province, and it is the headwater of the Huangshui River. The Datong River is located in the Qilian Mountains of the Northeastern Qinghai-Tibet Plateau, and it is the primary stream of the Huangshui River. Eight sampling sites (HS1-HS8) were collected along the midstream of the Hungshui River from 8 June to 19 June 2019 (Figure 1). Specific latitude and longitude information about each sampling site was shown as follows: HS1 $\left(36^{\circ} 20^{\prime} 28.9^{\prime \prime} \mathrm{N}, 102^{\circ} 50^{\prime} 07.4^{\prime \prime} \mathrm{E}\right)$, HS2 $\left(36^{\circ} 28^{\prime} 39.2^{\prime \prime} \mathrm{N}, 102^{\circ} 25^{\prime} 10.8^{\prime \prime} \mathrm{E}\right), \mathrm{HS} 3\left(36^{\circ} 50^{\prime} 07.0^{\prime \prime} \mathrm{N}, 101^{\circ} 58^{\prime} 00.5^{\prime \prime} \mathrm{E}\right), \mathrm{HS} 4\left(36^{\circ} 19^{\prime} 20.4^{\prime \prime} \mathrm{N}\right.$, $\left.101^{\circ} 48^{\prime} 57.8^{\prime \prime} \mathrm{E}\right), \mathrm{HS} 5\left(37^{\circ} 21^{\prime} 54.7^{\prime \prime} \mathrm{N}, 101^{\circ} 32^{\prime} 38.7^{\prime \prime} \mathrm{E}\right), \mathrm{HS} 6\left(37^{\circ} 35^{\prime} 45.5^{\prime \prime} \mathrm{N}, 101^{\circ} 09^{\prime} 18.4^{\prime \prime} \mathrm{E}\right)$, HS7 $\left(37^{\circ} 44^{\prime} 53.8^{\prime \prime} \mathrm{N}, 100^{\circ} 31^{\prime} 38.3^{\prime \prime} \mathrm{E}\right)$, and HS8 $\left(37^{\circ} 15^{\prime} 09.3^{\prime \prime} \mathrm{N}, 101^{\circ} 24^{\prime} 51.8^{\prime \prime} \mathrm{E}\right)$. Two liters of water samples were collected $2 \mathrm{~m}$ from the middle point of the river. One liter of water samples was filtered through a $20-\mu \mathrm{m}$ mesh (Millipore Corporation, Billerica, MA, USA) to remove large particles or organisms and subsequently filtered through $0.22-\mu \mathrm{m}$ polycarbonate membranes (Millipore Corporation, Billerica, MA, USA). The filters were frozen at $-80^{\circ} \mathrm{C}$ until further processing. The remaining water samples were transported to the laboratory in dark cooling boxes and processed 3-5 h after sampling within $4 \mathrm{~h}$ for immediate physicochemical analysis.
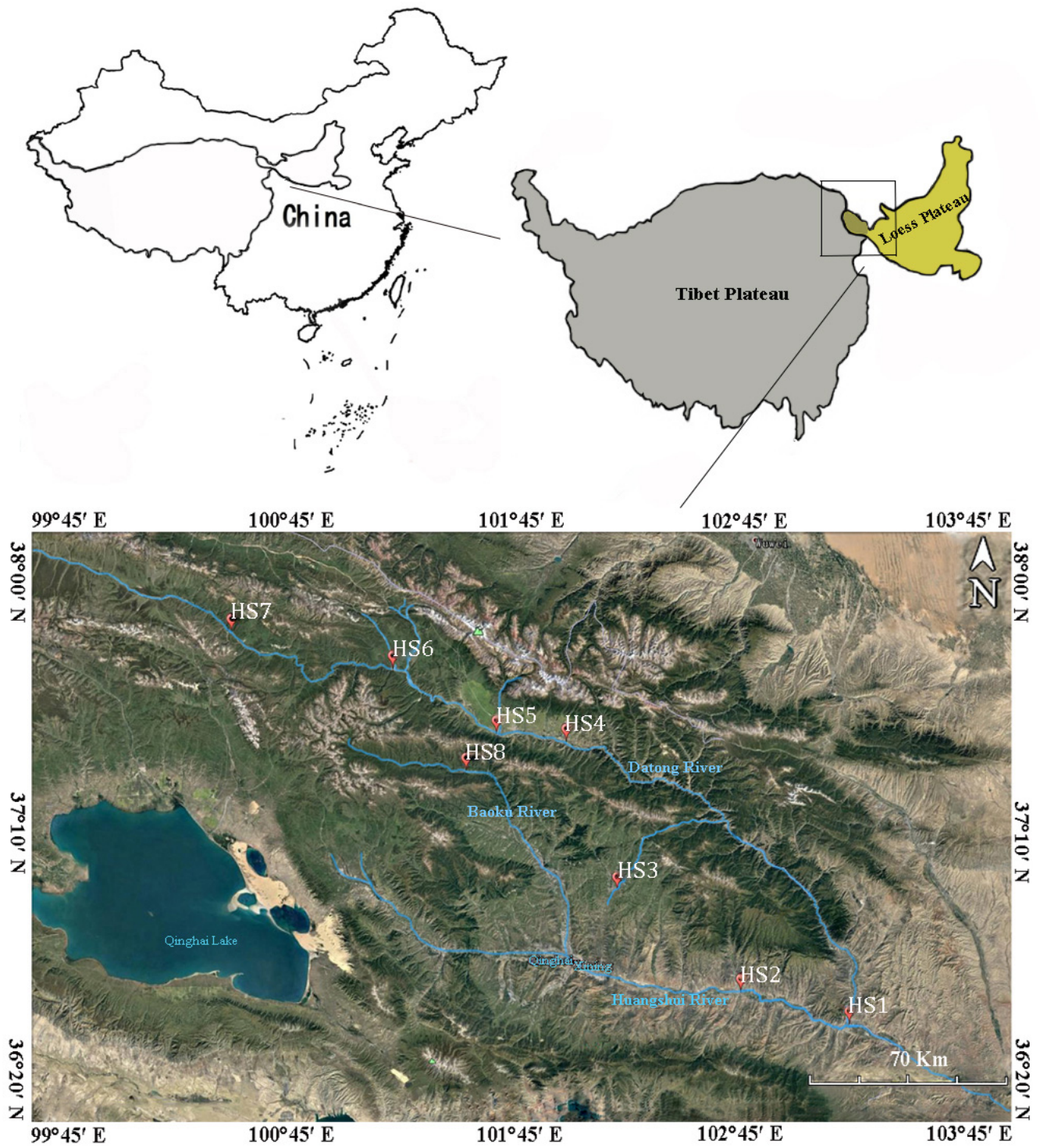

Figure 1. Distribution of the sampling sites in the Huangshui River. Map image and geographical information were cited from Google Earth Pro (version 7.1.8.3036). 


\subsection{Physicochemical Analyses}

Water chemistries such as the temperature, $\mathrm{pH}$, and dissolved oxygen (DO) were monitored in situ using YSI Pro2030 (YSI Incorporated, Yellow Springs, OH, USA). The total phosphorus (TP); total nitrogen (TN); permanganate index $\left(\mathrm{COD}_{\mathrm{Mn}}\right) ; \mathrm{NH}_{4}{ }^{+}-\mathrm{N}$; As; and metal ions $\left(\mathrm{Cr}^{6+}, \mathrm{Cu}, \mathrm{Zn}, \mathrm{Pb}, \mathrm{Cd}\right.$, and $\left.\mathrm{Hg}\right)$ were analyzed at the Qinghai Fishery Environment Monitoring Station. TP, TN, and $\mathrm{Cr}^{6+}$ were analyzed using a dual-beam ultraviolet (UV)-visible spectrophotometer (TU-1901, Persee, Beijing, China). As and Hg were analyzed using an atomic fluorescence photometer (AFS-230E, HaiGuang, Beijing, China), and the metal ions were determined using a graphite furnace flame atomic absorption spectrophotometer (AA6300, Shimadzu, Kyoto, Japan). Many environmental factors are related to the distribution of planktonic bacterial communities, but most of these factors have strong contributory relationships. The environmental factors screened in this study were $\mathrm{pH}$, altitude, $\mathrm{TN}, \mathrm{TP}, \mathrm{NH}_{4}{ }^{+}-\mathrm{N}, \mathrm{COD}_{\mathrm{Mn}}$, and $\mathrm{Cr}^{6+}$.

\subsection{DNA Extraction, Polymerase Chain Reaction, and Illumina Miseq Sequencing}

Microbial community genomic DNA was extracted from the water samples using the E.Z.N.A. ${ }^{\circledR}$ water DNA Kit (Omega Bio-tek, Norcross, GA, USA) in accordance with the manufacturer's instructions. The final DNA concentration and purity were determined by a NanoDrop 2000 UV-vis spectrophotometer (Thermo Scientific, Wilmington, NC, USA), and the DNA quality was checked by $1 \%$ agarose gel electrophoresis. The V3-V4 hypervariable regions of the bacteria $16 \mathrm{~S}$ rRNA gene were amplified with primers $338 \mathrm{~F}$ (5'-ACTCCTACGGGAGGCAGCAG-3') and 806R (5'-GGACTACHVGGGTWTCTAAT-3') by a thermocycler PCR system (GeneAmp 9700, ABI, Waltham, MA, USA). The PCR reactions were conducted using the following program: 3 min of denaturation at $95^{\circ} \mathrm{C}, 27$ cycles of $30 \mathrm{~s}$ at $95^{\circ} \mathrm{C}, 30 \mathrm{~s}$ for annealing at $55^{\circ} \mathrm{C}, 45 \mathrm{~s}$ for elongation at $72{ }^{\circ} \mathrm{C}$, and a final extension at $72{ }^{\circ} \mathrm{C}$ for $10 \mathrm{~min}$. The PCR reactions were performed in triplicate using $20-\mu \mathrm{L}$ mixtures containing $4 \mu \mathrm{L}$ of $5 \times$ FastPfu buffer, $2 \mu \mathrm{L}$ of 2.5-mM dNTPs, $0.8 \mu \mathrm{L}$ of each primer $(5 \mu \mathrm{M})$, $0.4 \mu \mathrm{L}$ of FastPfu polymerase, and $10 \mathrm{ng}$ of template DNA. The resulting PCR products were extracted from $2 \%$ agarose gel, further purified using the AxyPrep DNA Gel Extraction Kit (Axygen Biosciences, Union City, CA, USA), and quantified using QuantiFluor ${ }^{\text {TM_ST }}$ (Promega, Madison, WI, USA), according to the manufacturer's protocols.

Purified amplicons were pooled equimolarly and paired-end sequenced $(2 \times 300)$ on an Illumina MiSeq platform (Illumina, San Diego, CA, USA), according to the standard protocols by Majorbio Bio-Pharm Technology Co., Ltd. (Shanghai, China).

\subsection{Processing of Sequencing Data}

Raw fastq files were demultiplexed, quality-filtered by trimmomatic, and merged by FLASH with the following criteria: (i) the 300-bp reads were truncated at any site receiving an average quality score of $<20$ over a 50 -bp sliding window, and the truncated reads shorter than $50 \mathrm{bp}$ were discarded; reads containing ambiguous characters were also discarded; (ii) only overlapping sequences longer than $10 \mathrm{bp}$ were assembled according to their overlapped sequence. The maximum mismatch ratio of the overlap region was 0.2. Reads that could not be assembled were discarded; (iii) samples were distinguished according to the barcode and primers, and the sequence direction was adjusted and exact barcode matched, with 2 nucleotide mismatches in the primer matching.

Operational taxonomic units (OTUs) with $97 \%$ similarity cutoff $[20,21]$ were clustered using UPARSE version 7.1 [20], and chimeric sequences were identified and removed. The taxonomy of each OTU representative sequence was analyzed by RDP Classifier version 2.2 [22] against the $16 \mathrm{~S}$ rRNA database (SILVA SSU 132) using a confidence threshold of 0.7 .

\subsection{Statistical Analysis and Functional Prediction}

All samples were randomly resampled to 56,234 reads on the basis of the minimum number of sequences to eliminate the effect of the sequencing depth on subsequent 
analyses [23]. We evaluated the alpha diversity using the indices of the observed richness (OTUs) and Chao [24], the diversity indices of Shannon and Simpson [25], and Good's coverage. Nonmetric multidimensional scaling was performed on the OTU data using Bray-Curtis distance matrices to examine the differences in bacterial community among the water samples. The environmental factors were screened through a variance inflation factor (VIF) analysis to retain those with low collinearity. The VIF is a measure of collinearity among predictor variables within a multiple regression. It is calculated by taking the variance ratio of all betas of a given model divided by the variance of a single beta. The environmental factors screened in this study were as follows: $\mathrm{COD}_{\mathrm{Mn}}, \mathrm{Cr}^{6+}$, altitude, $\mathrm{pH}$, $\mathrm{TN}, \mathrm{TP}$, and $\mathrm{NH}_{4}{ }^{+}-\mathrm{N}$. A canonical correspondence analysis (CCA) was performed to determine the environmental variables associated with the changes in the bacterioplankton community structure using the vegan package. Linear discriminant analysis (LDA) effect size (LEfSe) is an algorithm for high-dimensional biomarker discovery and explanation, which identifies genomic features (genes, pathways, or taxa) characterizing the differences between two or more biological conditions [26]. In the present study, LEfSe was conducted to identify differential microbial functions between the main stream and tributary using an alpha parameter of 0.05 and an LDA threshold value of 3.5. Differences between two independent groups were evaluated by the Mann-Whitney $U$ test. PICRUSt (phylogenetic investigation of communities by reconstruction of unobserved states) was used to predict the microbial functions and metabolic pathways [27]. Moreover, the functional profiles of the bacterial communities were predicted using PICRUSt2 from the Kyoto Encyclopedia of Genes and Genomes (KEGG) pathways.

\section{Results}

\subsection{Environmental Characteristics}

The environmental characteristics of the samples from the eight investigated sites are summarized in Table 1 . The elevation of the eight sampling sites ranged from $1728 \mathrm{~m}$ to $3436 \mathrm{~m}$, and the sites were generally considered as high plateau areas. The surface water temperature ranged from $6.8^{\circ} \mathrm{C}$ to $17.2^{\circ} \mathrm{C}$, and the $\mathrm{pH}$ ranged from 8.34 to 8.47 , indicating a weak alkaline. The $\mathrm{Hg}$ ranged from $0.03 \mathrm{mg} / \mathrm{mL}$ to $0.11 \mathrm{mg} / \mathrm{mL}$, which was significantly lower in HS1 and HS2. A similar trend was found for As $\mathrm{mg} / \mathrm{mL}$ (MannWhitney $U$ test, $p<0.05$ ). From the upper reaches to the lower reaches of the Datong River (HS7-HS3), the DO level showed a downward trend. On the contrary, the TN level showed an upward trend. $\mathrm{The}^{\mathrm{Cr}}{ }^{6+}, \mathrm{Cu}, \mathrm{Zn}, \mathrm{Pb}$, and $\mathrm{Cd}$ levels remained consistent in the eight investigated sites.

Table 1. The water quality parameters of the different sampling sites.

\begin{tabular}{ccccccccc}
\hline Sample Site & HS1 & HS2 & HS3 & HS4 & HS5 & HS6 & HS7 & HS8 \\
\hline $\mathrm{T}\left({ }^{\circ} \mathrm{C}\right)$ & 13 & 14 & 13 & 17.20 & 16.00 & 9.30 & 6.80 \\
$\mathrm{pH}$ & 8.47 & 8.34 & 8.42 & 8.35 & 8.46 & 8.39 & 8.39 & 8.30 \\
$\mathrm{Altitude}(\mathrm{m})$ & 1728 & 1960 & 2630 & 2741 & 2838 & 3096 & 3436 & 2942 \\
$\mathrm{DO}(\mathrm{mg} / \mathrm{L})$ & $/$ & $/$ & 6.20 & 7.80 & 6.30 & 6.90 & 7.30 & 7.10 \\
$\mathrm{TN}(\mathrm{mg} / \mathrm{L})$ & 1.06 & 1.70 & 2.41 & 2.39 & 1.54 & 1.83 & 1.33 \\
$\mathrm{TP}(\mathrm{mg} / \mathrm{L})$ & 0.01 & 0.02 & 0.01 & 0.01 & 0.01 & 0.01 & 0.01 \\
$\mathrm{NH}_{4}^{+}-\mathrm{N}(\mathrm{mg} / \mathrm{L})$ & 0.17 & 0.16 & 0.14 & 0.19 & 0.19 & 0.16 & 0.14 \\
$\mathrm{Cr}^{6+}(\mathrm{mg} / \mathrm{L})$ & 0.01 & 0.01 & 0.01 & 0.01 & 0.01 & 0.01 & 0.01 \\
$\mathrm{COD}$ (mg/L) & $/$ & $/$ & 1.60 & 2.08 & 2.24 & 2.00 & 0.12 \\
$\mathrm{Cu}(\mathrm{mg} / \mathrm{mL})$ & 0.50 & 0.50 & 0.50 & 0.50 & 0.50 & 0.50 & 0.50 \\
$\mathrm{Zn}(\mathrm{mg} / \mathrm{L})$ & 0.03 & 0.03 & 0.03 & 0.03 & 0.03 & 0.03 & 0.03 \\
$\mathrm{~Pb}(\mathrm{mg} / \mathrm{L})$ & 0.01 & 0.01 & 0.01 & 0.01 & 0.01 & 0.01 & 0.03 \\
$\mathrm{Cd}(\mathrm{mg} / \mathrm{mL})$ & 0.50 & 0.50 & 0.50 & 0.50 & 0.50 & 0.50 & 0.50 \\
$\mathrm{Hg}(\mathrm{mg} / \mathrm{mL})$ & 0.03 & 0.03 & 0.11 & 0.11 & 0.11 & 0.11 & 0.03 \\
$\mathrm{As}(\mathrm{mg} / \mathrm{mL})$ & 0.03 & 0.03 & 0.68 & 0.69 & 0.49 & 0.80 & 0.11 \\
\hline
\end{tabular}




\subsection{Diversity and Structure of the Bacterioplankton Communities}

After quality filtering, a total of 497,604 valid reads (ranging from 56,234 to 69,445 per sample) were generated from eight sampling sites along the Huangshui River. All the samples were randomly resampled to 56,234 reads, and the reserved sequences were clustered into a total of 2384 OTUs. Good's coverage (all samples, 99.80\% $\pm 0.14 \%$ ) suggested that the majority of the microbial species present in the samples were detected. The rarefaction curves tended to approach the saturation plateau, and the Shannon curves were stable (Figure S1), indicating a sufficient sampling depth of all the libraries. The microbial diversity index listed in Table 2 comprised community richness indices (Ace and Chao) and community diversity indices (Shannon and Simpson). The Shannon index of the water samples of HS4, HS6, and HS8, which indicated bacterial diversity, was significantly higher than that of the other sampling sites. The range of Chao was 58.33 to 1764.65, whereas the range of Ace was 111.46 to 1765.84, which were considered richness indices. HS6 had the highest level of the Chao and Ace indices, whereas HS5 had the lowest (Table 2). Except for HS5, HS1 and HS2 in the main stream had lower $\alpha$ diversities than the samples in the tributary.

Table 2. Diversity index of microorganisms in each sampling sites.

\begin{tabular}{ccccccc}
\hline $\begin{array}{c}\text { Sampling } \\
\text { Site }\end{array}$ & $\begin{array}{c}\text { Sequence } \\
\text { Number }\end{array}$ & Shannon & Simpson & Ace & Chao & Coverage \\
\hline HS1 & 69,445 & 0.55 & 0.75 & 423.91 & 175.63 & $99.90 \%$ \\
HS2 & 56,403 & 0.69 & 0.58 & 184.05 & 104.15 & $99.93 \%$ \\
HS3 & 63,972 & 2.47 & 0.27 & 464.03 & 469.37 & $99.83 \%$ \\
HS4 & 56,234 & 4.34 & 0.03 & 382.38 & 383.50 & $99.96 \%$ \\
HS5 & 67,826 & 0.31 & 0.89 & 111.46 & 58.33 & $99.97 \%$ \\
HS6 & 59,560 & 5.05 & 0.06 & 1765.84 & 1764.35 & $99.67 \%$ \\
HS7 & 65,202 & 1.535 & 0.32 & 979.80 & 610.00 & $99.61 \%$ \\
HS8 & 58,962 & 4.97 & 0.02 & 640.05 & 641.02 & $99.91 \%$ \\
\hline
\end{tabular}

The OTUs were classified into 34 phyla, 78 classes, 216 orders, 386 families, and 821 genera (Table S1). Differences in the bacterial community composition were observed among different groups (Figure 2A,B and Figure 3A,B). Across all the sampling sites, the bacterioplankton communities were dominated by Proteobacteria and Firmicutes, and the relative abundance of these two phyla accounted for $77.48 \%$ and $12.08 \%$, respectively. Notably, the relative abundance of Proteobacteria in HS1, HS2, HS5, and HS7 was above $99 \%$, and it was as high as $99.98 \%$ at the HS5 sampling site. Interestingly, Proteobacteria dominated the sampling sites, but its classes were distributed differently. The abundance of Alphaproteobacteria was markedly different among the eight sampling sites, with a higher amount at the HS5 and HS7 sites (95.93\% and $93.53 \%$, respectively) and a lower amount at the HS4 and HS6 sites ( $8.68 \%$ and $5.52 \%$, respectively). The Gammaproteobacteria was the most abundant class in HS6 (55.163\%), whereas only $0.73 \%$ Gammaproteobacteria OTUs were detected in HS7 (Table S2). At the taxonomic level of genera, the bacterial communities of different sampling sits were different (Figure 3A). Acidiphilum $(0.03-86.16 \%)$ and Acidocella (0-95.9\%) were the most abundant genera, and they had a polar distribution within all the sampling sites. Remarkably, Pseudomonas was the dominant genus in HS3 $(18.15 \%)$, and Aeromonas was dominant in HS6 (19.77\%), whereas only a few Pseudomonas and Aeromonas OTUs were detected in the other sampling sites (Table S3). 


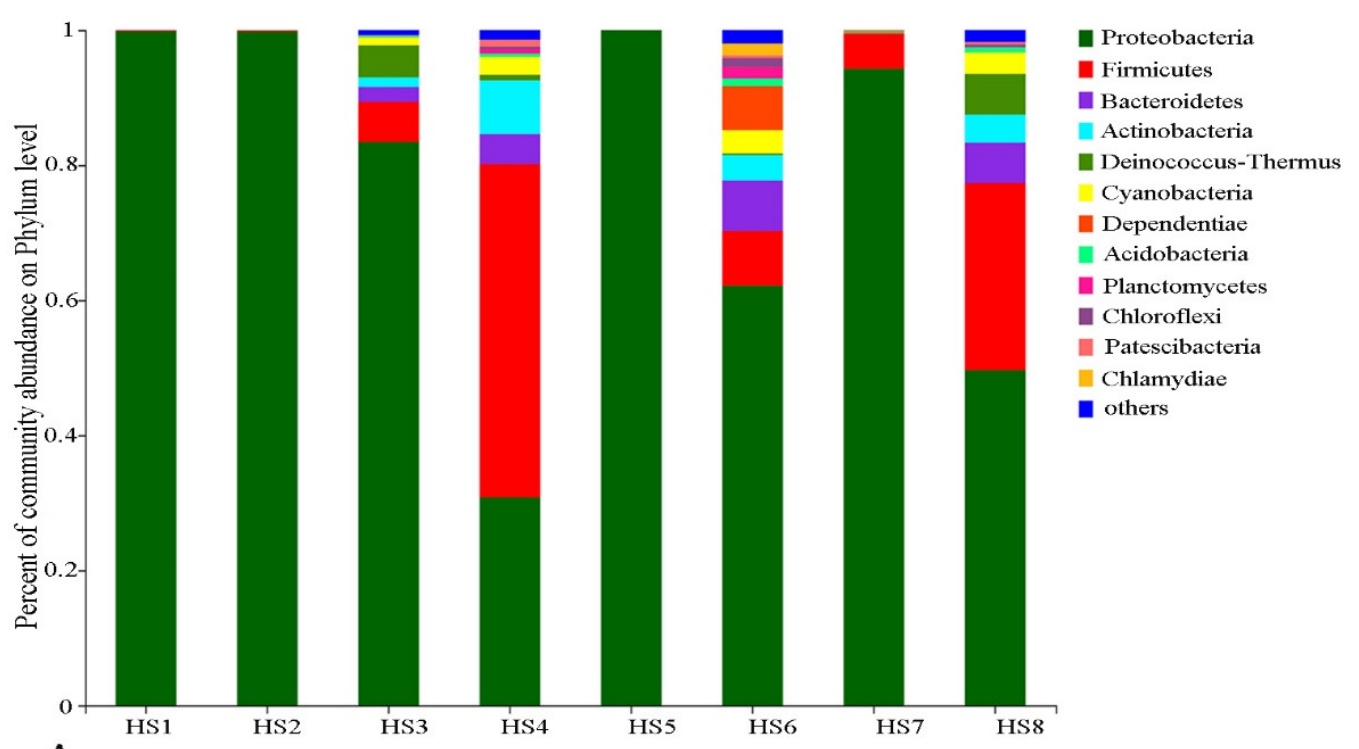

A

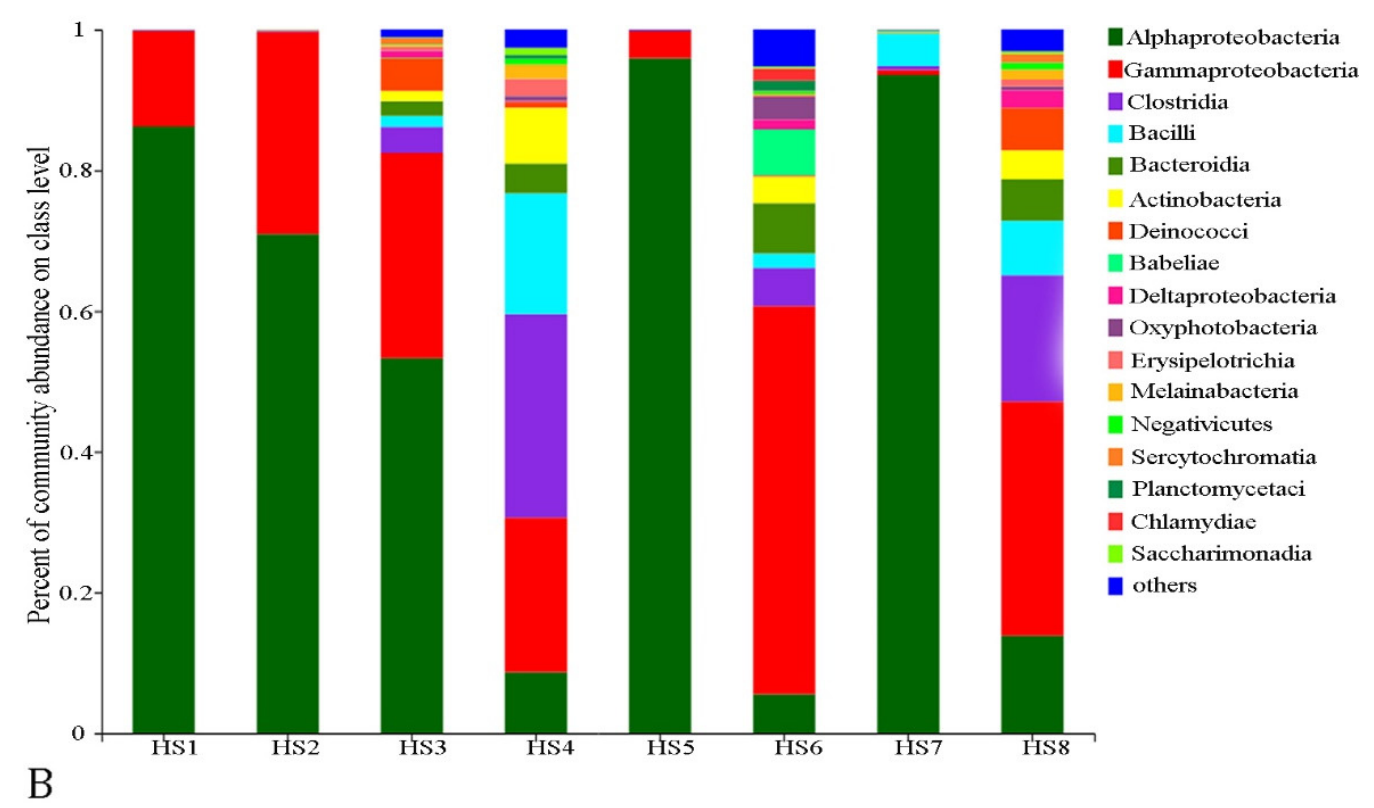

Figure 2. Bacterial composition of different sampling sites from the Huangshui River, the ecotone zone of Qinghai Plateau and Loess Plateau, China. (A) The relative abundance of the dominant bacterial phylum and (B) relative abundance of the dominant bacterial class are shown in a stack plot. The relative abundances are based on the $\geq 97 \%$ similarity clusters of the OTUs.

Multivariate statistical analyses were conducted to compare the structure of the bacterial communities in different sampling sites. The principal coordinate analysis (PCoA) plot showed the first two PCs, which accounted for $37.77 \%$ and $23.78 \%$ of the total variation in the bacterioplankton communities, and the samples from the main stream were clustered (Figure 3B). ANOSIM revealed no significant differences $(p=0.376)$ in the bacterial community structures between the main stream and tributary stream. 

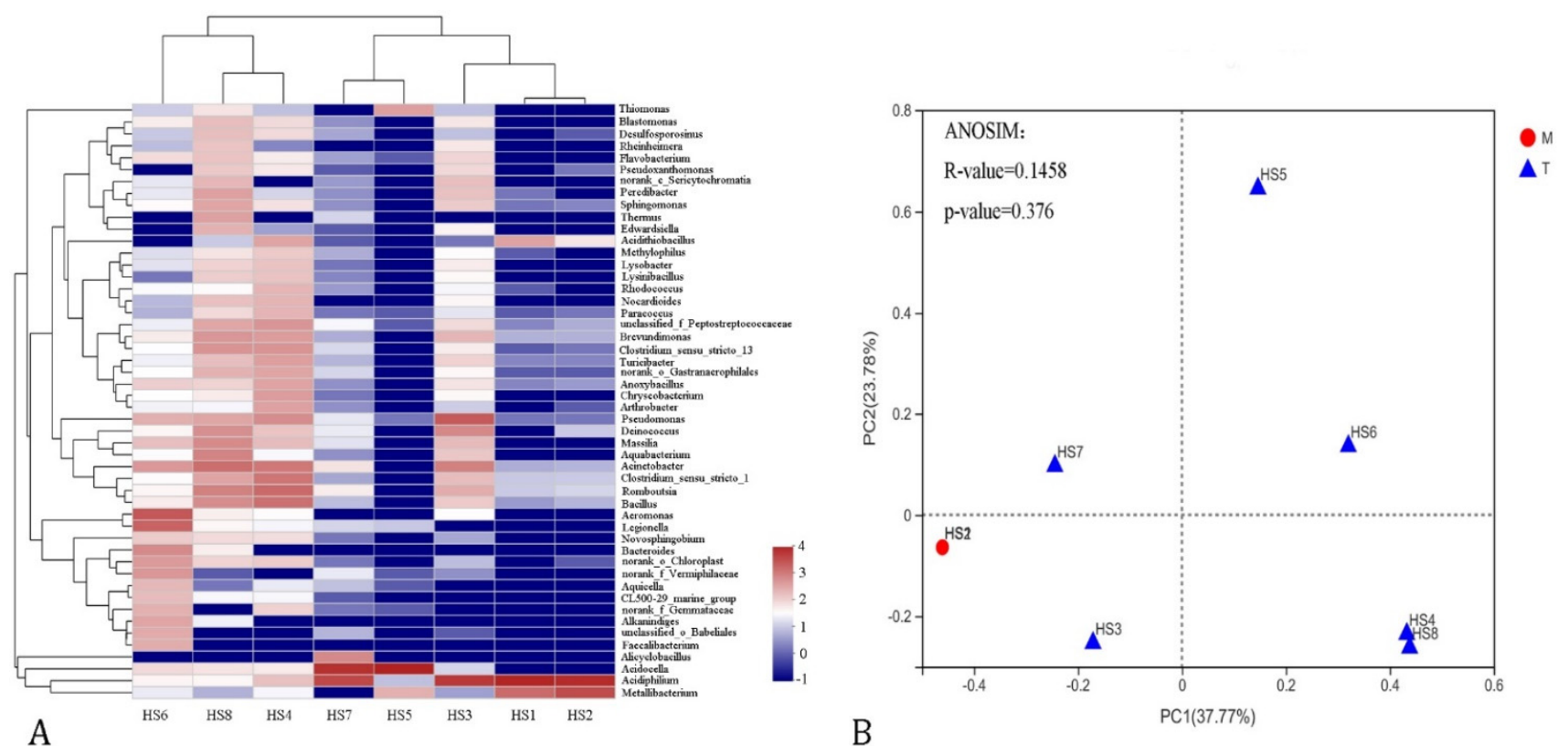

Figure 3. (A) A hierarchical clustering heatmap showing the main bacterial species in different groups at the genus level. Each rectangle is colored on the basis of a $\log _{10}$ value of the taxa percentage, as shown in the legend at the right of the plot. The top tree showed the clustering relationship of the samples. (B) A principal coordinates analysis of the main stream (red) and tributary stream (blue) of the Huangshui River based on the composition and abundance of the bacterial communities at the OUT level.

\subsection{Correlation Analysis of Bacterioplankton Communities and Environmental Factors}

In this study, the water temperature; altitude; and 13 physicochemical parameters, including the $\mathrm{pH}$ and concentrations of $\mathrm{DO}, \mathrm{TN}, \mathrm{TP}, \mathrm{NH}_{4}{ }^{+}-\mathrm{N}, \mathrm{Cr}^{6+}, \mathrm{COD}_{\mathrm{Mn}}, \mathrm{Cu}, \mathrm{Zn}, \mathrm{Pb}, \mathrm{Cd}$, $\mathrm{Hg}$, and As, were considered to evaluate their relative contributions to the bacterial community and genera. A canonical correspondence analysis [27] was performed to determine the environmental variables associated with changes in the bacterioplankton community structure (Figure 4). The first axis accounted for $31.22 \%$ of the total variance, whereas the second axis accounted for $26.69 \%$, indicating that the selected environmental factors led to differences in the bacterioplankton community structures. For correlations between environmental indicators and genera, the results showed that $\mathrm{TP}$ and $\mathrm{Cr}^{6+}$ contributed positively to Acidiphilium and Metallibacterium but contributed negatively to Acidocella and Acinetobacter. Furthermore, Aeromonas and Legionella seemed to be positively correlated with altitude and $\mathrm{COD}_{\mathrm{Mn}}$. 


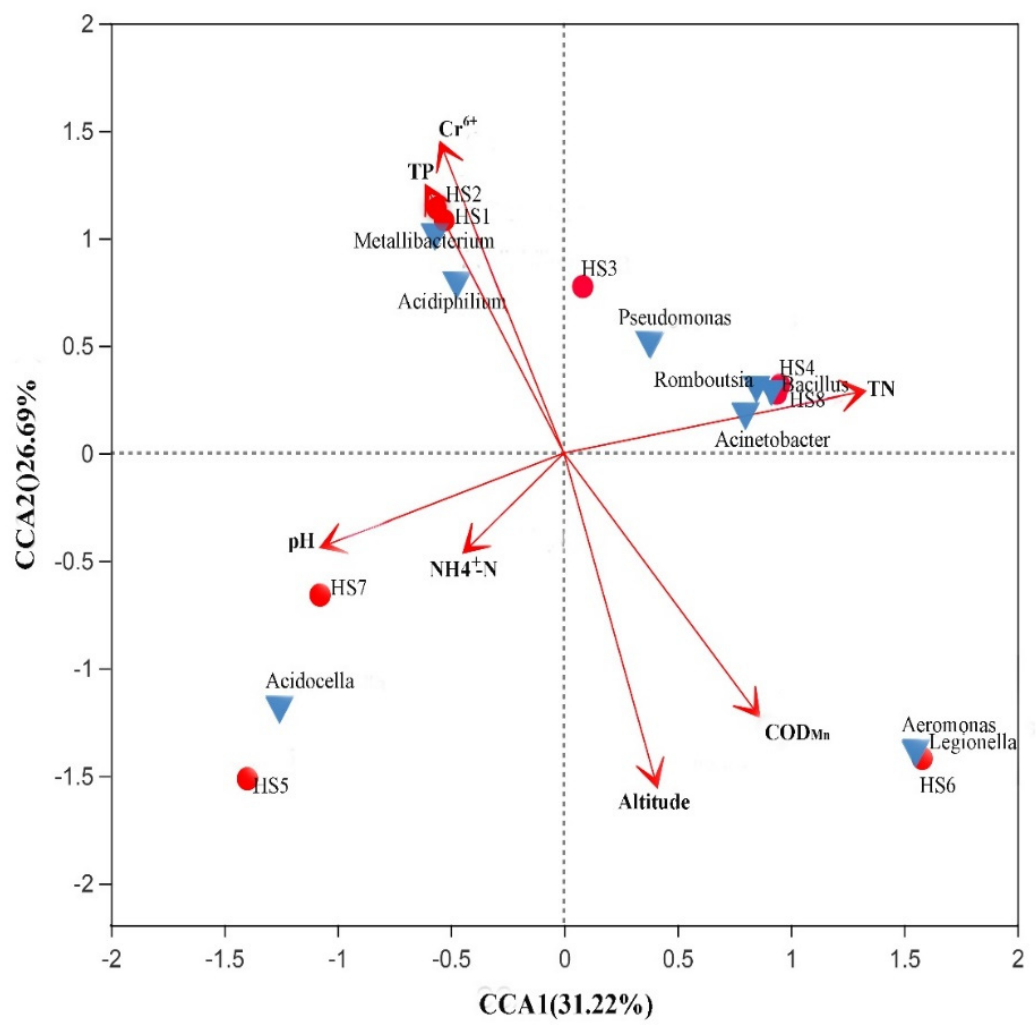

Figure 4. Canonical correspondence analysis (CCA) graph for the microorganism community and environmental factors. Red-filled circles indicate the water samples at the HS1-HS8 sites in the Huangshui River. Blue triangles indicate the top 8 genera among the eight sampling sites.

\subsection{Functional Prediction by PICRUSt2}

A community prediction analysis using PICRUSt 2 was performed to determine the functions of the observed bacterioplankton. The results indicated that the main functional gene families were related to metabolism, environmental information processing, genetic information processing, and cellular processes (Figure 5a). Of all the different functional pathways identified, carbohydrate metabolism, amino acid metabolism, global and overview maps, energy metabolism, and membrane transport were substantially overrepresented compared with other pathways. However, no significant differences between the main stream and tributary microbial assemblages were found in the relative abundances of the three core metabolic pathways, including the carbohydrate metabolism, amino acid metabolism, and global and overview maps. In addition, rivers are the main recipients of pollutants and xenobiotics imported from river basins. Most aquatic organisms and bacteria are exposed to these xenobiotics [28]. Therefore, we focused on the functional genes of xenobiotic biodegradation and metabolism, and the 13 corresponding KEGG pathways were analyzed (Figure $5 b$ ). The average relative abundance of benzoate degradation was the highest, followed by drug metabolism-cytochrome P450 and aminobenzoate degradation. The main stream microbial assemblages had a high abundance of KEGG orthologs (Kos), which belonged to human diseases and cellular processes. Similarly, the tributary had a high abundance of $\mathrm{KO}$, which belonged to the metabolism (Figure S2). In addition, several fairly abundant pathways were related to human diseases, including antibiotic resistance, cancers, and neurogenerative and infectious diseases. Among these diseases, antibiotic resistance was the most dominant (antimicrobial; Table S4). 


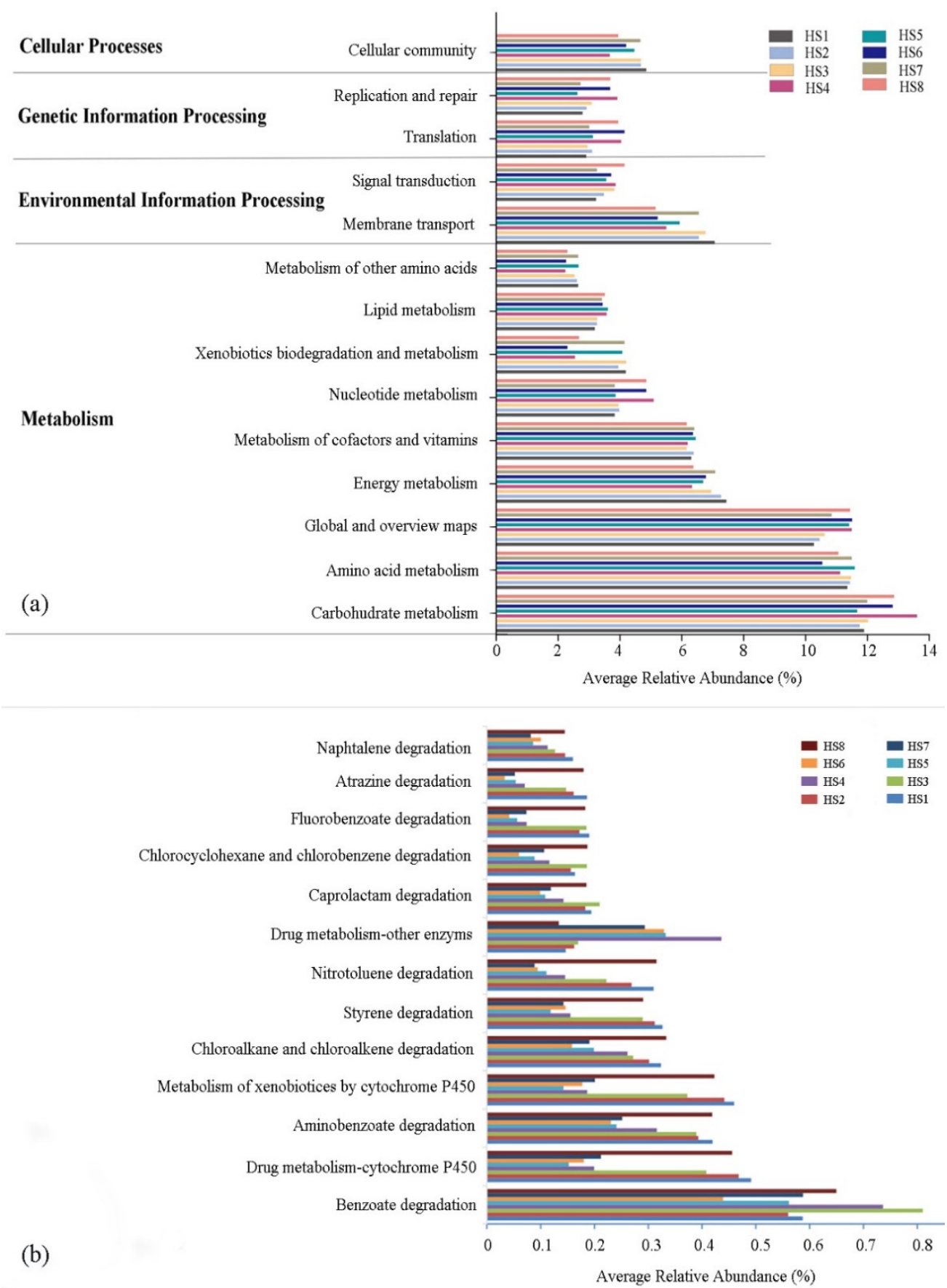

Figure 5. Functional level 1 categories (Kyoto Encyclopedia of Genes and Genomes (KEGG) (a)) of the bacterial communities and richness of the genes related to xenobiotic biodegradation and metabolism (b), as predicted by the Phylogenetic Investigation of Communities by Reconstruction of Unobserved States (PICRUSt2) analysis. Functional groups with less than $1 \%$ relative abundance are not included.

\section{Discussion}

Bacteria play an important role in ensuring and maintaining the environment and ecological processes of river ecosystems, particularly in plateaus, which are a hotspot of microbial diversity. Comparatively few reports have focused on the bacterial diversity of the Qinghai-Tibet Plateau. Most studies have focused on bacterial communities in salts, gas fields, and polluted lakes $[29,30]$. Therefore, we aimed to study the Huangshui River to supplement the full-scale research of the river ecosystem on the plateau. 
In our study, the Chao1 richness and Shannon index of the river samples were lower than those of plain rivers based on previous papers, which may be due to the special geographical environment. For instance, Fan et al. [31] reported that the Chao1 and Shannon indices of the planktonic bacterial community in the upper section of the tidal reach in the Yangtze River ranged from 764.33 to 861 and 4.36 to 4.72 , respectively (Table 1). Hauptmann et al. [32] investigated the bacterioplankton community along a small Arctic River and revealed that the Chao1 indices ranged from 1408 to 19,117 OTUs, and the Shannon indices ranged from 5.6 to 10.8 per sample. Yang et al. [33] reported that the Chao1 and Shannon indices of bacteria in the Songhua River, one of the seven largest rivers in China, ranged from 1249.26 to 5780.18 and 2.85 to 5.21, respectively, which were higher than those of the Huangshui River (Table 2). Considering that the air is relatively thinner and the concentration of atmospheric suspended particle matter is lower in the plateau region, the solar UV radiation reaching the plateau surface is less attenuated. A high UV intensity can destroy the molecular structure of DNA or RNA in microbial organisms, resulting in low microbial diversities in plateau rivers [34]. However, the Chao1 and Shannon indices of the Heihe River, also known as the Plateau River, were similar to those of the Huangshui River, ranging from 300.546 to 2014.803 and 0.789 to 5.529, respectively [35]. Similar results were also found in the microbial abundance of stream biofilms, which was negatively correlated with altitude [36]. Given the extreme unique climate of the Qinghai-Tibet Plateau, including cold, hypoxia, and strong UV radiation, microorganisms may produce a series of community changes and genetic selection [37].

The decrease in alpha diversity at the input sites from the tributary of the Datong River (HS5) indicates that the tributary inputs less diverse bacterial communities into the main stream of the Datong River. The diversity of the two tributaries of the Datong River and Baoku River is significantly higher than that of the main stream of the Huangshui River, but the diversity of HS1 and HS2 has not increased because of the confluence of the two tributaries (Table 2). This result shows that the microbial community in the main stream of the Huangshui River does not change significantly because of the influx of tributaries. Moreover, the highly diverse communities from the Datong River and Baoku River are concealed by the low diversity of the main stream of the Huangshui River.

The bacterial community in the water samples was different with regards to the phylum, class, and genus (Figure 2A,B and Figure 3A,B). The high-throughput sequencing data showed that the dominant phylum was Proteobacteria, accounting for $99.98 \%$ of the sequences, followed by Firmicutes (49.38\%). Due to extreme conditions, such as low temperature and oligotrophy, the rivers in the Qinghai-Tibet Plateau (also termed "the Third pole") have similar environmental characteristics to those in the polar regions. However, the most abundant endemic taxa identified in the Huangshui River were different from those found in the polar regions (e.g., Bacteroidetes, Alphaproteobacteria, and Gammaproteobacteria in Antarctica; Betaproteobacteria, Bacteroidetes, and Cyanobacteria in the Arctic) [38]. This result may be due to the severe climates of these regions (the Qinghai Plateau and Loess Plateau, Antarctica, and the Arctic), and their geographic isolation has led to a high level of endemism. This result is similar to the results of the local and international studies of planktonic bacterial communities in rivers [39] and lakes [40,41]. The relative abundance of Proteobacteria is $77.48 \%$, which is considered the most abundant phylum in wastewater $[42,43]$. However, notably, proteobacteria, which is the dominant phylum, consists of Alphaproteobacteria and Gammaproteobacteria, and the relative content of the two classes of bacteria is as high as 76.82\%. Moreover, Alphaproteobacteria and Gammaproteobacteria can be found in freshwater and seawater, but they are more abundant in seawater [44-46]. This finding may be due to the salt mineral resources, such as the gypsum and calcium Glauber's salt mine, which are widely distributed along the banks of the Huangshui River. Furthermore, the microbial composition of the Huangshui River is significantly different from other freshwater rivers at the class level.

At the genus level, the top six species in relative abundance at each sampling site were Acidiphilium, Acidocella, Metallibacterium, Acinetobacter, Pseudomonas, and Aeromonas 
(Table S3). Based on previous studies, Acidiphilium, Acidocella, and Metallibacterium dominate the microbial communities within mineral-leaching environments or acidic aquatic environments [47]. The $\mathrm{pH}$ of the Huangshui River was 8.34-8.47, indicating a weak alkaline, and the content of metal ions was low, which was not a suitable condition for the enrichment of these microorganisms (Table 1). Apart from its unique hydrology, biology, climate, and landform, the study area had notable geological and metallogenic conditions. Zeng [48] found that the Huangshui River had evident heavy metal pollution for the contents of $\mathrm{Cd}, \mathrm{Pb}, \mathrm{Hg}$, and $\mathrm{Cr}$ in muddy sediments, which were all higher than the background values under natural conditions. We inferred that these acidophilic bacteria-namely, Acidiphilium, Acidocella, and Metallibacterium - in the upper reaches of the Huangshui River were derived from the sediments along the river, which were affected by strong winds and rainfall. Interestingly, HS4-7 is located in the same river system, but the bacterial communities at HS5 and -7 are very different from those at HS4 and HS6. According to our analysis, because there are mining areas near HS5 and HS7, acidophilic bacteria transferred to water bodies due to precipitation, wind, sand, etc., but the water environment was not suitable for its growth, so the levels of Acidocella near the mining site were high, while at the sampling sites far away from the mining site were low. In addition, we identified diverse taxa of potential pathogens, such as Acinetobacter, Pseudomonas, and Aeromonas. The abundance of Acinetobacter was primarily contributed by HS8 and HS4, whereas Pseudomonas and Aeromonas were primarily contributed by HS3 and HS6, respectively. Acinetobacter and Pseudomonas are major opportunistic waterborne pathogens causing hospital-acquired infections. These bacteria are opportunistic pathogens that do not affect healthy people. However, they can infect immunocompromised patients in hospitals (especially patients in intensive care units) with infections such as pneumonia, bacteremia, and urinary tract infections. Therefore, the presence of these bacteria in water may increase their colonization, with subsequent hospital-acquired infections [49]. The quality and quantity of rivers are influenced by human activities when they flow through different settlement types. Ibekwe et al. reported that urban areas, wastewater treatment work, and agricultural areas had significantly different effects on the microbial composition of the Santa Ana River in Southern California [50]. Aeromonas-associated cases of gastroenteritis are generally considered waterborne. Aeromonas spp. are primarily aquatic organisms that may be readily isolated from lakes, rivers, estuarine environments, sewage effluents, groundwater, drinking waters, and a wide range of raw foods [51]. The HS6 sampling site has a fish breeding station, which is an aquaculture area; thus, the enrichment of Aeromonas could be explained in this sampling site.

The bacterial community in river water can be affected by many factors, including the temperature, nutrient concentration, $\mathrm{pH}$, and DO [52-54]. The physical and chemical indicators of the water bodies in the upper main stream and tributaries of the Heihe River vary at different sampling sites, and the water environment has a high spatial heterogeneity because of the variations in the environmental pressure carried by different river sections and the surrounding human activities [55]. In this study, the $\mathrm{Cr}^{6+}, \mathrm{TP}$, altitude, and $\mathrm{COD}_{\mathrm{Mn}}$ indicated the observed variability in the bacterioplankton community composition (Figure 4). The heavy metal ion $\mathrm{Cr}^{6+}$ has been proven to have an impact on the bacterial diversity [56]. $\mathrm{COD}_{\mathrm{Mn}}$ is a comprehensive index to measure the degree of water pollution, which can greatly represent the organic matter components in water. The higher the $\mathrm{COD}_{\mathrm{Mn}}$ is, the greater the degree of water pollution. Excessive phosphorus leads to eutrophication and deteriorates the water quality because of human activities and agriculture. Moreover, inorganic phosphorus is an important nitrogen source for heterotrophic bacteria. TP and $\mathrm{Cr}^{6+}$ increase the abundance of Acidiphilium and Metallibacterium, indicating that these two genera have good adaptability to changes in organic pollutions and heavy metal ions in rivers.

Understanding the functional characteristics of bacterial communities is of great significance to the study of ecosystem processes and community composition mechanisms. In the current study, the functional results showed that the overall functional profiles of 
the bacterial communities in the different samples were similar, and the pathways for carbohydrate metabolism and amino acid metabolism were enriched in all the samples. As the metabolic pathways of the core resources, the two pathways are the potential driving force for the structure and function of the microbial community in the river [28]. This was consistent with previous studies that the carbohydrate metabolism and amino acid metabolism of the bacterial communities might be highly correlated with environmental stress, such as a low temperature $[57,58]$. In addition, several pathways for xenobiotics biodegradation and metabolism were enriched in the bacterioplankton communities, suggesting that the bacterioplankton community plays an important role in self-purification and exogenous contamination remediation in water ecosystems [28]. Several studies have reported on environmental bacterial functions related to human diseases, as reviewed by Sandifer [59]. Antibiotic resistance has been shown to spread throughout the environment through mechanisms such as urban and agricultural runoffs, wind, and biological forces such as animals and humans [60]. The increasing number of reports on antimicrobial resistance is undeniably a troubling truth challenging humanity's movement towards its global health agenda [61]. Given that rivers such as the Huangshui River are the main sources of water for drinking and personal and household hygiene in many developing countries, many people who use these polluted waters without prior treatment might be exposed to negative health effects because of the lack of adequate potable water supplies [56,62]. Our results suggested potential health risks of water sources in this area. Therefore, the effective governance of untreated sewage in rivers is of great importance.

\section{Conclusions}

The present study provided the first insights into the bacterial communities of the upper and middle reaches of the Huangshui River using high-throughput sequencing in the ecotone zone of the Qinghai Plateau and Loess Plateau. As a plateau river, the Huangshui River had a relatively low bacterial community diversity compared with plain rivers. Despite the similarities in the environmental conditions, the main taxa compositions of the bacterial communities were distinct between the Huangshui River and the polar regions (the Arctic and Antarctica). Proteobacteria was the dominant phyla, followed by Firmicutes. Given the salt mineral resources widely distributed along the banks of the Huangshui River, the Alphaproteobacteria and Gammaproteobacteria were significantly enriched. The predominant bacterial genera were Acidiphilium, Acidocella, Metallibacterium, and Acinetobacter. The diverse taxa of potential pathogens, such as Acinetobacter, Pseudomonas, and Aeromonas, were also identified. We also found site differences in the bacterial community structure in the river water. The water physical properties (e.g., $\mathrm{Cr}^{6+}, \mathrm{TP}$, and $\mathrm{COD}_{\mathrm{Mn}}$ ); altitude; and land use (e.g., urban land cover and aquaculture) could determine the distribution of the bacterioplankton composition. PICRUSt2 revealed that the overall functional profiles of the bacterial communities in the different samples were similar, and notably, our results suggested the potential health risks of water sources in this area. Furthermore, this work provided valuable insight into the composition of the plankton bacterial community and its relationship with the environmental factors in the Huangshui River in the ecotone zone of the Qinghai Plateau and Loess Plateau.

Supplementary Materials: The following are available online at https:/ / www.mdpi.com/article/ 10.3390 /microorganisms9112260/s1. Figure S1: Rarefaction curves of all the sequences of different sampling sites of the Huangshui River, the ecotone zone of the Qinghai Plateau and Loess Plateau, China. Figure S2: A LDA analysis determined the differences in the bacterial functions between the main stream (M) and tributary (T). Table S1: OTU taxonomic statistics of the different sampling sites. Table S2: Composition of the top 6 microorganism groups in each sampling at the class level. Table S3: Composition of the top 6 microorganism groups in each sampling at the genus level. Table S4: Details of the KEGG database on Level 3.

Author Contributions: Q.Z. was responsible for the design, data analysis, and writing. Z.W. performed the statistical analyses. S.J., G.W., J.Z. (Juan Zhao) and H.G. conducted the sampling and 
the lab work. J.H., S.W. and Y.L. conducted the experimental work. A.L. and J.Z. (Jinyong Zhang) obtained the funding. All authors have read and agreed to the published version of the manuscript.

Funding: This work was supported by grants from the National Key Research and Development Program of China (Grant No. 2020YFD0900300), and "key technology and development of food safety" project of MOST (2019YFC1606000), Qinghai KLPA project (2019/2020), Wuhan Science and Technology Project (2019020701011480), and FEBL project (2016FBZ04).

Institutional Review Board Statement: The study was conducted according to the guidelines of the Declaration of Helsinki, and approved by the Animal Ethical and Welfare Committee of the Institute of Hydrobiology, Chinese Academy of Sciences, China (approval number: IHBCAS-20160905).

Data Availability Statement: The raw reads were deposited in the NCBI Sequence Read Archive database (Accession Number: SRP294338).

Acknowledgments: We would like to acknowledge Shanghai Majorbio Bio-pharm Technology Co., Ltd. for providing the free online Majorbio I-Sanger Cloud Platform (www.i-sanger.com accessed on 2 January 2021) to analyze the raw data.

Conflicts of Interest: The authors declare no conflict of interest.

\section{References}

1. Fuhrman, J.A. Microbial community structure and its functional implications. Nature 2009, 459, 193-199. [CrossRef] [PubMed]

2. Zhou, J.; Yang, H.; Tang, F.; Koide, R.T.; Cui, M.; Liu, Y.; Sun, Q.; Insam, H.; Zhang, Q. Relative roles of competition, environmental selection and spatial processes in structuring soil bacterial communities in the Qinghai-Tibetan Plateau. Appl. Soil Ecol. 2017, 117, 223-232. [CrossRef]

3. Pernthaler, J. Predation on prokaryotes in the water column and its ecological implications. Nat. Rev. Microbiol. 2005, 3, 537-546. [CrossRef] [PubMed]

4. Kirchman, D.L.; Dittel, A.I.; Malmstrom, R.R.; Cottrell, M.T. Biogeography of major bacterial groups in the Delaware Estuary. Limnol. Oceanogr. 2005, 50, 1697-1706. [CrossRef]

5. Kuang, J.; Huang, L.; He, Z.; Chen, L.; Hua, Z.; Jia, P.; Li, S.; Liu, J.; Li, J.; Zhou, J. Predicting taxonomic and functional structure of microbial communities in acid mine drainage. ISME J. 2016, 10, 1527-1539. [CrossRef]

6. Martins, G.; Terada, A.; Ribeiro, D.C.; Corral, A.M.; Brito, A.G.; Smets, B.F.; Nogueira, R. Structure and activity of lacustrine sediment bacteria involved in nutrient and iron cycles. FEMS Microbiol. Ecol. 2011, 77, 666-679. [CrossRef] [PubMed]

7. Oikonomou, A.; Filker, S.; Breiner, H.W.; Stoeck, T. Protistan diversity in a permanently stratified meromictic lake (Lake Alatsee, SW Germany). Environ. Microbiol. 2015, 17, 2144-2157. [CrossRef]

8. Simek, K.; Hornák, K.; Jezbera, J.; Nedoma, J.; Znachor, P.; Hejzlar, J.; Sed'a, J. Spatio-temporal patterns of bacterioplankton production and community composition related to phytoplankton composition and protistan bacterivory in a dam reservoir. Aquat. Microb. Ecol. 2008, 51, 249-262. [CrossRef]

9. Yu, M.; Liu, S.; Li, G.; Zhang, H.; Xi, B.; Tian, Z.; Zhang, Y.; He, X. Municipal wastewater effluent influences dissolved organic matter quality and microbial community composition in an urbanized stream. Sci. Total Environ. 2020, 705, 135952. [CrossRef]

10. Neal, C.; Robson, A. A summary of river water quality data collected within the Land-Ocean Interaction Study: Core data for eastern UK rivers draining to the North Sea. Sci. Total Environ. 2000, 251, 585-665. [CrossRef]

11. Ling, J.; Jiang, Y.F.; Wang, Y.S.; Dong, J.D.; Zhang, Y.Y.; Zhang, Y.Z. Responses of bacterial communities in seagrass sediments to polycyclic aromatic hydrocarbon-induced stress. Ecotoxicology 2015, 24, 1517-1528. [CrossRef]

12. Jeffries, T.C.; Schmitz Fontes, M.L.; Harrison, D.P.; Van-Dongen-Vogels, V.; Eyre, B.D.; Ralph, P.J.; Seymour, J.R. Bacterioplankton Dynamics within a Large Anthropogenically Impacted Urban Estuary. Front. Microbiol. 2015, 6, 1438. [CrossRef]

13. Jin, Z.; Ji, F.Y.; Xu, X.; Xu, X.Y.; Chen, Q.K.; Li, Q. Microbial and metabolic characterization of a denitrifying phosphorusuptake/side stream phosphorus removal system for treating domestic sewage. Biodegradation 2014, 25, 777-786. [CrossRef]

14. Besaury, L.; Ghiglione, J.F.; Quillet, L. Abundance, activity, and diversity of archaeal and bacterial communities in both uncontaminated and highly copper-contaminated marine sediments. Mar. Biotechnol. 2014, 16, 230-242. [CrossRef]

15. Hu, Z.-Y.; Bao, Y.-X.; Cheng, H.-Y.; Zhang, L.-L.; Ge, B.-M. Research progress on ecology of natural wetland zoobenthos in China. Chin. J. Ecol. 2009, 28, 959.

16. Li, N.; Chen, A.; Yang, C.; Sun, Y.; Ma, G.; Ma, Q. Impacts of urbanization on water quality and macrobenthos community structure upstream in the Huangshui river. Acta Ecol. Sin. 2017, 37, 3570-3576.

17. Qi, M.; Li, N.; Sun, Y.; Yang, C.; Bai, L. Community structure analysis of macrobenthos in the upper reaches of Huangshui river in Qinghai Province. J. Qinghai Univ. 2019, 37, 1-8.

18. Bai, X.; Yan, C. Effects of eco-environmental construction projects on soil and water loss in Huangshui River basin. Bull. Soil Water Conserv. 2013, 33, 217-305.

19. Zhao, C.; Dong, X.; Xin, W.-R.; Zhang, F.-C.; Yang, X.-Y. Analysis of factors of soil erosion and some ways of rehabilitation in Huangshui River of Qinghai Province. Res. Soil Water Conserv. 2008, 15, 200-202. 
20. Edgar, R.C. UPARSE: Highly accurate OTU sequences from microbial amplicon reads. Nat. Methods 2013, 10, 996-998. [CrossRef] [PubMed]

21. Stackebrandt, E.; GOEBEL, B.M. Taxonomic note: A place for DNA-DNA reassociation and 16S rRNA sequence analysis in the present species definition in bacteriology. Int. J. Syst. Evol. Microbiol. 1994, 44, 846-849. [CrossRef]

22. Wang, Q.; Garrity, G.M.; Tiedje, J.M.; Cole, J.R. Naive Bayesian classifier for rapid assignment of rRNA sequences into the new bacterial taxonomy. Appl. Environ. Microbiol. 2007, 73, 5261-5267. [CrossRef]

23. Weiss, S.J.; Xu, Z.; Amir, A.; Peddada, S.; Bittinger, K.; Gonzalez, A.; Lozupone, C.; Zaneveld, J.R.; Vazquez-Baeza, Y.; Birmingham, A. Effects of Library Size Variance, Sparsity, and Compositionality on the Analysis of Microbiome Data; PeerJ PrePrints: San Diego, CA, USA, 2015; pp. 2167-9843.

24. Chiu, C.-H.; Chao, A. Estimating and comparing microbial diversity in the presence of sequencing errors. PeerJ 2016, 4, e1634. [CrossRef] [PubMed]

25. Sekiguchi, H.; Watanabe, M.; Nakahara, T.; Xu, B.; Uchiyama, H. Succession of bacterial community structure along the Changjiang River determined by denaturing gradient gel electrophoresis and clone library analysis. Appl. Environ. Microbiol. 2002, 68, 5142-5150. [CrossRef]

26. Segata, N.; Izard, J.; Waldron, L.; Gevers, D.; Miropolsky, L.; Garrett, W.S.; Huttenhower, C. Metagenomic biomarker discovery and explanation. Genome Biol. 2011, 12, 1-18. [CrossRef] [PubMed]

27. Langille, M.G.; Zaneveld, J.; Caporaso, J.G.; McDonald, D.; Knights, D.; Reyes, J.A.; Clemente, J.C.; Burkepile, D.E.; Thurber, R.L.V.; Knight, R. Predictive functional profiling of microbial communities using $16 \mathrm{~S}$ rRNA marker gene sequences. Nat. Biotechnol. 2013, 31, 814-821. [CrossRef] [PubMed]

28. Ren, Z.; Wang, F.; Qu, X.D.; Elser, J.J.; Liu, Y.; Chu, L.M. Taxonomic and Functional Differences between Microbial Communities in Qinghai Lake and Its Input Streams. Front. Microbiol. 2017, 8, 2319. [CrossRef] [PubMed]

29. Han, Q.S.; Huang, J.; Long, D.F.; Wang, X.B.; Liu, J.J. Diversity and community structure of ectomycorrhizal fungi associated with Larix chinensis across the alpine treeline ecotone of Taibai Mountain. Mycorrhiza 2017, 27, 487-497. [CrossRef]

30. Wang, W.J.; Yi, Y.J.; Yang, Y.F.; Zhou, Y.; Zhang, S.H.; Wang, X.; Yang, Z.F. Impact of anthropogenic activities on the sediment microbial communities of Baiyangdian shallow lake. Int. J. Sediment Res. 2020, 35, 180-192. [CrossRef]

31. Fan, L.; Song, C.; Meng, S.; Qiu, L.; Zheng, Y.; Wu, W.; Qu, J.; Li, D.; Zhang, C.; Hu, G. Spatial distribution of planktonic bacterial and archaeal communities in the upper section of the tidal reach in Yangtze River. Sci. Rep. 2016, 6, 1-11. [CrossRef]

32. Hauptmann, A.L.; Markussen, T.N.; Stibal, M.; Olsen, N.S.; Elberling, B.; Bælum, J.; Sicheritz-Pontén, T.; Jacobsen, C.S. Upstream freshwater and terrestrial sources are differentially reflected in the bacterial community structure along a small Arctic river and its estuary. Front. Microbiol. 2016, 7, 1474. [CrossRef]

33. Yang, Y.; Li, S.; Gao, Y.; Chen, Y.; Zhan, A. Environment-driven geographical distribution of bacterial communities and identification of indicator taxa in Songhua River. Ecol. Indic. 2019, 101, 62-70. [CrossRef]

34. Wu, B.; Tian, J.Q.; Bai, C.M.; Xiang, M.C.; Sun, J.Z.; Liu, X.Z. The biogeography of fungal communities in wetland sediments along the Changjiang River and other sites in China. ISME J. 2013, 7, 1299-1309. [CrossRef]

35. Qian-Qian, Z.; Sheng-Long, J.; Ke-Mao, L.; Zhen-Bing, W.; Hong-Tao, G.; Jin-Wen, H.; Shu-Yi, W.; Yao-Yao, L.; Guo-Jie, W.; Ai-Hua, L. Community structure of bacterioplankton and its relationship with environmental factors in the upper reaches of the Heihe River in Qinghai Plateau. Environ. Microbiol. 2021, 23, 1210-1221. [CrossRef]

36. Wilhelm, L.; Besemer, K.; Fragner, L.; Peter, H.; Weckwerth, W.; Battin, T.J. Altitudinal patterns of diversity and functional traits of metabolically active microorganisms in stream biofilms. ISME J. 2015, 9, 2454-2464. [CrossRef] [PubMed]

37. Li, Y.Q.; Chai, Y.H.; Wang, X.S.; Huang, L.Y.; Luo, X.M.; Qiu, C.; Liu, Q.H.; Guan, X.Y. Bacterial community in saline farmland soil on the Tibetan plateau: Responding to salinization while resisting extreme environments. BMC Microbiol. 2021, 21, 1-14. [CrossRef] [PubMed]

38. Liu, K.S.; Yao, T.D.; Pearce, D.A.; Jiao, N.Z.; Zeng, Y.H.; Guo, B.X.; Liu, Y.Q. Bacteria in the lakes of the Tibetan Plateau and polar regions. Sci. Total Environ. 2021, 754, 142248. [CrossRef]

39. Liu, T.; Zhang, A.N.; Wang, J.; Liu, S.; Jiang, X.; Dang, C.; Ma, T.; Liu, S.; Chen, Q.; Xie, S. Integrated biogeography of planktonic and sedimentary bacterial communities in the Yangtze River. Microbiome 2018, 6, 16. [CrossRef] [PubMed]

40. Newton, R.J.; Jones, S.E.; Eiler, A.; McMahon, K.D.; Bertilsson, S. A guide to the natural history of freshwater lake bacteria. Microbiol. Mol. Biol. Rev. 2011, 75, 14-49. [CrossRef]

41. Percent, S.F.; Frischer, M.E.; Vescio, P.A.; Duffy, E.B.; Milano, V.; McLellan, M.; Stevens, B.M.; Boylen, C.W.; Nierzwicki-Bauer, S.A. Bacterial community structure of acid-impacted lakes: What controls diversity? Appl. Environ. Microbiol. 2008, 74, 1856-1868. [CrossRef] [PubMed]

42. Lin, Y.; Li, D.; Zeng, S.; He, M. Changes of microbial composition during wastewater reclamation and distribution systems revealed by high-throughput sequencing analyses. Front. Environ. Sci. Eng. 2016, 10, 539-547. [CrossRef]

43. Novo, A.; André, S.; Viana, P.; Nunes, O.C.; Manaia, C.M. Antibiotic resistance, antimicrobial residues and bacterial community composition in urban wastewater. Water Res. 2013, 47, 1875-1887. [CrossRef] [PubMed]

44. Böckelmann, U.; Manz, W.; Neu, T.R.; Szewzyk, U. Characterization of the microbial community of lotic organic aggregates ('river snow') in the Elbe River of Germany by cultivation and molecular methods. FEMS Microbiol. Ecol. 2000, 33, 157-170. [CrossRef]

45. Schweitzer, B.; Huber, I.; Amann, R.; Ludwig, W.; Simon, M. $\alpha$-and $\beta$-Proteobacteria control the consumption and release of amino acids on lake snow aggregates. Appl. Environ. Microbiol. 2001, 67, 632-645. [CrossRef] [PubMed] 
46. Stevens, H.; Stübner, M.; Simon, M.; Brinkhoff, T. Phylogeny of Proteobacteria and Bacteroidetes from oxic habitats of a tidal flat ecosystem. FEMS Microbiol. Ecol. 2005, 54, 351-365. [CrossRef] [PubMed]

47. Johnson, D.B.; Rolfe, S.; Hallberg, K.B.; Iversen, E. Isolation and phylogenetic characterization of acidophilic microorganisms indigenous to acidic drainage waters at an abandoned Norwegian copper mine. Environ. Microbiol. 2001, 3, 630-637. [CrossRef]

48. Zeng, F. Assessment of Heavy Metal Pollution in Xining Section of the Huangshui River. J. Salt Lake Res. 2017, 25, 8-12+59.

49. Huang, H.I.; Shih, H.Y.; Lee, C.M.; Yang, T.C.; Lay, J.J.; Lin, Y.E. In vitro efficacy of copper and silver ions in eradicating Pseudomonas aeruginosa, Stenotrophomonas maltophilia and Acinetobacter baumannii: Implications for on-site disinfection for hospital infection control. Water Res. 2008, 42, 73-80. [CrossRef]

50. Ibekwe, A.M.; Ma, J.C.; Murinda, S.E. Bacterial community composition and structure in an Urban River impacted by different pollutant sources. Sci. Total Environ. 2016, 566, 1176-1185. [CrossRef] [PubMed]

51. Pablos, M.; Rodriguez-Calleja, J.M.; Santos, J.A.; Otero, A.; Garcia-Lopez, M.L. Occurrence of motile Aeromonas in municipal drinking water and distribution of genes encoding virulence factors. Int. J. Food Microbiol. 2009, 135, 158-164. [CrossRef]

52. Kirchman, D.L.; Dittel, A.I.; Findlay, S.E.; Fischer, D. Changes in bacterial activity and community structure in response to dissolved organic matter in the Hudson River, New York. Aquat. Microb. Ecol. 2004, 35, 243-257. [CrossRef]

53. Li, Q.; Zhao, Y.; Zhang, X.; Wei, Y.; Qiu, L.; Wei, Z.; Li, F. Spatial heterogeneity in a deep artificial lake plankton community revealed by PCR-DGGE fingerprinting. Chin. J. Oceanol. Limnol. 2015, 33, 624-635. [CrossRef]

54. Wang, P.; Chen, B.; Yuan, R.; Li, C.; Li, Y. Characteristics of aquatic bacterial community and the influencing factors in an urban river. Sci. Total Environ. 2016, 569, 382-389. [CrossRef] [PubMed]

55. Qiu, Y.; Lu, C.; Xu, Z.; Wang, Y. Spatio-temporal variation characteristics and water pollution sources in the Huangshui River Basin. Acta Sci. Circumstantiae 2017, 37, 2829-2837.

56. Chen, S.; Wang, P.; Liu, H.; Xie, W.; Wan, X.S.; Kao, S.-J.; Phelps, T.J.; Zhang, C. Population dynamics of methanogens and methanotrophs along the salinity gradient in Pearl River Estuary: Implications for methane metabolism. Appl. Microbiol. Biotechnol. 2020, 104, 1331-1346. [CrossRef]

57. Dai, Y.; Yan, Z.; Jia, L.; Zhang, S.; Gao, L.; Wei, X.; Mei, Z.; Liu, X. The composition, localization and function of low-temperatureadapted microbial communities involved in methanogenic degradations of cellulose and chitin from Qinghai-Tibetan Plateau wetland soils. J. Appl. Microbiol. 2016, 121, 163-176. [CrossRef] [PubMed]

58. Mai, Y.Z.; Lai, Z.N.; Li, X.H.; Peng, S.Y.; Wang, C. Structural and functional shifts of bacterioplanktonic communities associated with spatiotemporal gradients in river outlets of the subtropical Pearl River Estuary, South China. Mar. Pollut. Bull. 2018, 136, 309-321. [CrossRef] [PubMed]

59. Sandifer, P.A.; Sutton-Grier, A.E.; Ward, B.P. Exploring connections among nature, biodiversity, ecosystem services, and human health and well-being: Opportunities to enhance health and biodiversity conservation. Ecosyst. Serv. 2015, 12, 1-15. [CrossRef]

60. Allen, H.K.; Donato, J.; Wang, H.H.; Cloud-Hansen, K.A.; Davies, J.; Handelsman, J. Call of the wild: Antibiotic resistance genes in natural environments. Nat. Rev. Microbiol. 2010, 8, 251-259. [CrossRef] [PubMed]

61. Wernli, D.; Jørgensen, P.S.; Morel, C.M.; Carroll, S.; Harbarth, S.; Levrat, N.; Pittet, D. Mapping global policy discourse on antimicrobial resistance. BMJ Glob. Health 2017, 2, e000378. [CrossRef] [PubMed]

62. Abia, A.L.K.; Alisoltani, A.; Keshri, J.; Ubomba-Jaswa, E. Metagenomic analysis of the bacterial communities and their functional profiles in water and sediments of the Apies River, South Africa, as a function of land use. Sci. Total Environ. 2018, 616, 326-334. [CrossRef] [PubMed] 